\title{
PRIVATE ISLAMIC HIGHER EDUCATION IN ASEAN ECONOMIC COMMUNITY (AEC) ERA
}

\author{
Mulyawan Safwandy Nugraha \\ Sekolah Tinggi Agama Islam (STAI) Sukabumi \\ Jl. Lio Balandongan Sirnagalih No. 74, Citamiang, Kota Sukabumi, \\ Jawa Barat, Indonesia 43161 \\ Email: mulyawan77@yahoo.co.id
}

\section{Dadang Sahroni}

Sekolah Tinggi Agama Islam (STAI) Sukabumi

Jl. Lio Balandongan Sirnagalih No. 74, Citamiang, Kota Sukabumi, Jawa Barat, Indonesia 43161

Email: dsdadangsahroni@gmail.com

\section{Aeni Latifah}

Sekolah Tinggi Agama Islam (STAI) Sukabumi

Jl. Lio Balandongan Sirnagalih No. 74, Citamiang, Kota Sukabumi, Jawa Barat, Indonesia 43161

Email: aenilatifah@gmail.com

\begin{abstract}
This article explores the challenge faced by Indonesia in ASEAN Economic Community (AEC) era. It is also revealed the Private Islamic Religion Institution (PTKIS) strategic to play its role and function in generating human resource. The method used is qualitative in the form of literature study. The result shows that PTKIS are required to adapt and see the AEC as an opportunity to change. A private status should be used as an institutional capital to create and innovate freely, by maximally utilizing the available resources. The management of a reputable institution is seen to be a significant factor for reinforcement. Aspects of visionary leadership, qualified lecturers, a curriculum that is responsive to a change, and an adequate infrastructure become a strengthening point toward the management accountability of universities in creating graduates who are competitive, skillful and qualified.
\end{abstract}

Keywords: Private Islamic Religious Institution (PTKIS), ASEAN Economic Community (AEC).

\footnotetext{
ABSTRAK

Artikel ini mengkaji tentang tuntutan yang dihadapi Indonesia dalam menghadapi Masyarakat Ekonomi ASEAN (MEA). Artikel ini juga memaparkan tentang peran strategis Perguruan Tinggi Keagamaan Islam Swasta (PTKIS) dalam memainkan peran dan fungsinya. Metoda penelitian yang digunakan adalah kualitatif berupa studi pustaka. Hasil kajian menunjuk.kan babwa PTKIS dituntut untuk beradaptasi dan melihat MEA sebagai suatu peluang untuk
} 
berubah. Status swasta dijadikan sebagai modal institusional (institusional capital) untuk berkereasi dan berinovasi secara leluasa, dengan mendayagunakan semaksimal mungkin sumber daya yang dimiliki. Tata kelola manajemen perguruan tinggi yang handal dipandang menjadi factor yang signifikan untuk diberikan penguatan. Aspek pimpinan yang visioner, dosen yang berkualitas, kurikulum yang responsif terhadap perubahan, dan sarana prasarana yang memadai menjadi bentuk penguatan terhadap akuntabilitas manajemen perguruan tinggi dalam menghasilkan lulusan yang berdaya saing, terampil dan berkualitas.

Kata Kunci: Perguruan Tinggi Keagamaan Islam Swasta (PTKIS), Masyarakat Ekonomi ASEAN (MEA).

\section{INTRODUCTION}

State and private universities in Indonesia are expected to compete regionally, nationally, and internationally. This competition can be done if each university can respond toward a rapid environmental change to meet customer satisfaction. The change that focuses on excellence and sustainable competitiveness need human resources (HR) who are tough and have the strength either independently or in groups within an organization. HR must be able and willing to carry out work with an intelligent, competitive and cooperative way for the benefit and advancement of the organization.

However, until now HR in Indonesia still have little competitiveness compared to countries in South East Asia or Asia. Based on the World Competitiveness Report 2010-2011, the competitiveness of Indonesian human resources ranks $44^{\text {th }}$. Thailand ranks $38^{\text {th }}$, China $27^{\text {th }}$, Brunei $28^{\text {th }}$, Malaysia $26^{\text {th }}$, and Singapore $3^{\text {rd }}$ (Schwab, Sala-i-Martin, Dervis, \& World Economic Forum, 2010).

Meanwhile, according to the UNDP (United Nations Development Programs) on Human Development Report 2011, Indonesia was ranked $124^{\text {th }}$ out of 187 countries in the world. Even more worrying there was a decline in ratings. Initially, in 1997, HDI (Human Development Index), and Indonesia ranked $99^{\text {th }}$, then in 2002 , the ranking dropped to $102^{\text {nd }}$. This conditions continued to decline being ranked $111^{\text {th }}$ in 2004 and ranked the $110^{\text {th }}$ in 2005 (UNDP, 2011). The HDI measured the comparison of life expectancy, literacy, education, and standard of living.

Issues related to $\mathrm{HR}$ also occurred in the Institute of Educator (Lembaga Pendidikan Tingi Keagamaan/LPTK). There are two main problems in LPTK, namely: a large number of LPTK in Indonesia and the low quality of LPTKs. In fact, LPTK is an institution that creates the educators. These educators are going to be the leader in creating qualified human resources.

The lack of human resources condition in Indonesia become a problem that must be taken seriously. Moreover, Indonesia is currently facing 
regional challenges such as ASEAN Economy Community (AEC). When AEC is enforced, the needs of skilled workers who are certified are preferred. In contrast, skilled workers who are not certified will be difficult to compete with skillfully certified personnel in getting a job. Moreover, when an Indonesian skilled worker is to compete in abroad, they must have a professional certificate that is not only recognized by Indonesia but also recognized by other countries.

In facing AEC, educational institutions in Indonesia, especially universities have difficulty in competing with others. Universities in Indonesia are also challenging to keep up with changes. Private Higher Education commonly experiences it (Perguruan Tinggi Swasta/PTS). There are still a lot of PTS which the quality is below standard and still far from expectations in producing superior human resources. Consequently, the PTS with under level of quality became bankrupt.

The readiness in facing AEC also has to be conducted by Private Islamic Religious Institution (Perguruan Tinggi Keagamaan Islam Swasta/PTKIS). Therefore, the strengthen action is needed to develop in order to make PTKIS ready for the AEC, including the strengthening of the management or governance. Universities are required to have efficient, transparent, and accountable management to have a clear direction to produce good quality and advantageous graduates (Asmawi, 2005). Therefore in this paper, it will be reviewed and outlined further towards the issues about PTKIS problem related to the management or governance through research activities in facing the ASEAN Economic Community or better known as AEC. The management of universities become the focus of this study due to the low quality of national higher education can be viewed from the low quality of service and management or governance. University as a public institution conduct the public services in the education field. Service is one of the factors considered by prospective students (both from domestic and foreign) to determine the choice.

The research conducted using a qualitative approach. According to Moloeng (2007) qualitative research is a type of research that aims to understand the phenomena experienced by study subjects holistically by describing using words, in a particular natural context and utilize natural methods. The phenomenon experienced by research subjects may include behaviors, perceptions, motivations, and actions. The type of research (based on place/space) used in this study is a library research.

\section{DISCUSSION AND ANALYSIS}

\section{Juridical Basis}

According to the Act No. 20 of 2003 on National Education System 
in Article 24 states that the provision of education and science development knowledge, in university it is applied freedom of academic and freedom of educational forum as well as the autonomy of science. The university has the freedom to manage their institution as a center of higher education, scientific research, and dedication to the community and university can obtain funds from public sources which the management that is done based on the public accountability principle. In Article 48 it is stated that the management of education funds is based on the principle of fairness, efficiency, transparency, and public accountability. Further in Chapter 14 of the management of education, Article 51 states that the management of higher education unit implemented based on the principle of autonomy, accountability, quality assurance, and transparent evaluation. Then, in chapter 16, containing about assessment, accreditation, and certification. As stated in article 57 of the assessment carried out in order to control the quality of education nationwide as a form of teaching accountability providers to the parties concerned. In Article 60 states about the accreditation of programs and educational units by the government and/or an independent institution authorized as a form of public accountability. Continued on article 66, explained that the government, local governments, boards of education, and school/madrasah exercise supervision over the education at all levels and types of education by their respective authorities. Supervision referred to in paragraph (1) shall be conducted with the principles of transparency and public accountability.

In the Indonesian Government Regulation No. 17 of 2010 on the management and delivery of education, in Article 3 states that management education is aimed at ensuring: 1) public access to educational services adequate, equitable, and affordable; 2) the quality and competitiveness of education and its relevance to the needs and/or condition of the people; and 3) the effectiveness, efficiency, and accountability in the management of education. In Article 49 paragraph (2) states that the management unit or a higher education program implemented based on the principle of autonomy, accountability, quality assurance, and transparent evaluation. More clearly in Article 58 explained that the units or education program shall establish education governance policies to ensure the efficiency, effectiveness, and accountability in the management education that binds: 1) unit or educational program in question; 2) educational institutions stakeholder representation on the unit or educational program in question; 3) learners unit or educational program in question; 4) parents/guardians of students in the unit or educational program in question; 5) teachers and education personnel in the unit or educational program in question; and 6) the another party is bound by the unit or educational program in question. 
Explicitly, in the Indonesian Government Regulation No. 66 of 2010 concerning amendments to the Government Regulation No. 17 of 2010 on the management and delivery of education, Article 58J mentioned that the management accountability and the implementation of compulsory education unit is realized by at least: 1) organize the governance of education unit based on the principles of governance education entity referred to in Article 49 paragraph $(2) ; 10 ; 2$ ) balance the number of students, the capacity of facilities and infrastructure, educators, staff and other resources; 3) education is not commercial; and 4) prepare reports providing education and financial reports in a timely, transparent, and accountable in accordance with the provisions of the legislation.

\section{The Sociological Basis}

The existence of PTKIS influenced by sociological aspects, among others affected by the formation of the ASEAN Community. ASEAN Community is a group formed by the countries in ASEAN. ASEAN Community was formed with the aim to improve the welfare of all ASEAN members to be able to face the competition on the regional and global scope. In the history of ASEAN countries unity, this is a very significant development in response to the care of human security that includes economic security, food security, health security, environmental security, personal security, community security and political security. Before ASEAN Community has been declared, it had been signed the CAFTA (ChinaASEAN Free Trade Area) in 2009 and began to be implemented in January 2010. The signing of CAFTA was motivated by China's economic rise and the movement of which skyrocketed in the last decade. This is an opportunity to improve the type and volume of partnership for both parties. Various reasons cause CAFTA expected to run acceleratively, of which China and ASEAN countries have a culture that tends same (Eastern nations), so the need (markets) are relatively equal and geographic location that facilitates the distribution process of supply and demand take place efficiently.

At the $14^{\text {th }}$ ASEAN Summit in Thailand in December 2008, there was a strategic decision, which all ASEAN countries have ratified the ASEAN Charter (ASEAN Charter) and agree The ASEAN Charter entered "entry to force" stage. So the three pillars of the ASEAN Community which include the ASEAN Economic Community, ASEAN Security Community, and the ASEAN Socio-Cultural Community which were originally planned to be implemented and targeted fully integrated in 2020, then accelerated into 2015. Consideration to this acceleration was the rise of China and India as new countries that were able to compete with the strength of the America economic map as a superpower to the problem of investment and the global 
economy as the result of Hakim research (Hakim, 2015). Because of the resurrection of these two countries stimulated other ASEAN countries to accelerate its vision with the hope to strengthen the competitiveness of the member countries of ASEAN. So that ASEAN member can respond and get a positive value from the rise of China and India to accelerate the ideals of ASEAN in 2015.

ASEAN Community Originally only has two pillars, the pillar of the economic and political pillar of security. Those two pillars have been longstanding. However, to establish further friendship between ASEAN countries, it was released the third pillar of the socio-cultural pillar. As it is known that the ASEAN countries have a common culture, through the fundamental social and cultural relationship between ASEAN member countries may soon be interwoven. The three pillars are interrelated and reinforce each other in achieving the goal attainment of sustainable peace, stability and welfare distribution in the region (ASEAN, 2009). ASEAN contributed in creating, maintaining security and stability for the region and the world. With the creation of safety and stability, all ASEAN members can focus on economic development and social culture (UNDP, 2011).

The implementation of the first pillar of ASEAN Community 2015 in the economic field since 2015 ahead to make ASEAN as a single market and production base internationally. On the economic support, the flow of goods, services, investment, skilled labor and capital flow freely done. Consumer protection, intellectual property rights (IPR), development of infrastructure, taxation and e-commerce to make ASEAN as a region with high competitiveness (competitive economic region). The implementation of the country's integration among Cambodia, Myanmar, Laos, and Vietnam, to make ASEAN as a economic development region and the building of economic relations with the outside of the region, to make ASEAN as a globally integrated region (integration into the global economy) (Hakim, 2015). Economic integration is part of the ASEAN visions 2020. The vision of ASEAN as follows.

".... to create a stable, prosperous, and highly competitive ASEAN Economic Region in the which there is a free flow of goods, services, investment, skilled labor, and free flow of capital, equitable economic, development and reduced poverty and socio-economic disparities in the year 2020."

The second pillar of the ASEAN Community 2015 is the security field (ASEAN Security Community). The cooperation form in the fields of security, namely in combating terrorism, human trafficking, drug trafficking, illegal fishing, and the arms trade. In this era of globalization, terrorism often involves several countries and not regarded the international border 
(transnational). Globalization increases violent activities in the form of terror. Rapid changes brought about by the process of globalization has led to a polarized society (Nassar, 2009). Globalization produces the marginalized and the weak society. The emergence of the marginalized and the weak society causing them to act against the law, violence, and commit acts of terror. Meanwhile, the issues of world concern, such as human trafficking, drug trafficking, illegal fishing, and the arms trade can occur across countries in the world (Hakim, 2015). Therefore, in dealing with the problem, it is required to conduct a cooperation between ASEAN countries in the shade of the ASEAN Security Community.

In Syncore Magz (2015) explained that for some countries in the region of Southeast Asia, three main pillars of the cooperation had been announced together; ASEAN Security Community, ASEAN Economic Community (AEC) and ASEAN Socio-Cultural Community (ASCC). Of these three pillars that need special attention is the third pillar relates to ASCC because there are six programs, namely: human development, social welfare and protection, social justice and rights, ensuring environmental sustainability, narrowing the development of GAP and building the ASEAN identity (ASEAN, 2009).

Regarding education as the third pillar in the form of socio-cultural aspects, it is hoped that education can prop up the ASEAN Community in 2015. Since a few years ago, the ASEAN countries once committed to establishing cooperation in the field of education, namely in 1995. Even before that, ASEAN has a network of higher education, namely the ASEAN University Network (AUN). AUN is the result of the High-Level Conference on the 4th ASEAN implemented in 1992. The purpose of the AUN establishment is to accelerate the development of solidarity and regional identity through the promotion of human resource development by strengthening the existing network at the university level and educational institutions featured in the region (Hakim, 2015).

All three pillars of the ASEAN member countries agreed within the framework of the ASEAN Community, namely the pillars of economic, security and socio-cultural, they overlap each other. Economic growth, movement of goods and services and investment will not be accomplished if there is no security aspect that ensures the smooth operation of the economy. Similarly, the socio-cultural aspects will not develop, if safety and the economy are not going well. Socio-cultural aspects are required for the development of a sense of togetherness and solidarity among ASEAN countries, including the development of human resources through education (Hakim, 2015). 
Equalization of the quality of human resources ASEAN community, of course, will further accelerate economic development as the main pillar of ASEAN Community. A major factor in the success and progress advocates together in the era of the ASEAN Community, especially in improving the competitiveness is determination. Competitiveness and human resource capacities are also institutional qualified, is an absolute requirement to maximize the potential benefits and opportunities of the ASEAN Community ("Kerjasama Fungsional Asean," n.d.). We must improve itself consistently to improve competitiveness. Of course, only with determination and consistency, Indonesia can feel tangible benefits for the ASEAN Community forward. Indonesia determinant factor at the regional level will also be able to encourage ASEAN to maintain its influence in the middle of the dynamics of international relations. Therefore, all ASEAN members should take a role not just be a spectator in any development of the world.

Indonesia should immediately improve itself to prepare the human resources that very competitive and global. Premises must prepare for the challenges and opportunities, especially for young professionals to compete with foreign workers who come to Indonesia. Challenges of Indonesia to the future is to create meaningful change in the daily life of its people.

\section{Academic Principle}

In Indonesia, the quality education image is still far from expectations (Nandika, n.d.). Education in Indonesia is quite apprehensive from time to time not being improved. A bleak portrait of Indonesia education certainly can not be separated from the situation in the field of ideology, political, economic, social and cultural in transition (Darmaningtyas, 2007). As evidence, the study results of UNDP (2004) regarding human development index showed Indonesia ranks 111th out of 177 countries. This is a bitter pill to swallow and become a blurred portrait in conducting education process in Indonesia.

The low ranking of Indonesia in the HDI into a complexity problems, especially with regard to the delivery of education, the problems that often arise include: low budget for education, the lack of quality and income of teachers/lecturers, lack of infrastructure, high cost of education, high surge, drop out high illiteracy, and the high number of graduates who become unemployed, can certainly not be considered as a technical issue of education. This overlap problem if not addressed systemically, may eventually roll like a snowball. The problem will be even greater and complex, as a result, would create a setback for Indonesia's education (Zamroni, 2012).

The college is an educational institution of formal education in Indonesia. As the highest educational institutions, Universities should play an 
active role in improving the quality of students and graduates who will plunge into the community and be a candidate of the professional workforce. Moreover, in facing the AEC market of free competition, Universities should be able to develop the various sectors which will increase the competitiveness. Education should be developed and evolved to improve the quality of Indonesian society. Therefore, the college with the help of the government strives to educate the nation to improve the country's level of life.

Learning quality in higher education is indeed resulting from the process quality as well. To improve the quality of the education, the process has been pursued by many lecturers, among them with every additional local content and coaching entrepreneurs on the student. Colleges have implemented education and training of entrepreneurs in universities. Thus, graduates besides having competence in the field can also be useful in society, especially in applying the guidance of entrepreneurs to the public so that the public has the entrepreneurial spirit, and can produce a product that has the same quality. In fact, it could compete with the products of other countries. With the participation of the government, universities, and private, Indonesia certainly can compete in AFTA 2015.

Meanwhile, through the addition of local content, students are expected not only has global knowledge but also a concern for sociocultural values surrounding them, Ki Hajar Dewantara forward the concept of local content to the idea of Trikon. One concept of Trikon is concentric. Concentric means not losing its personality, having united and communicate with other nations. Local content means human resources in Indonesia will love and value the local area as a form of self-defense in receiving global flows. Thus, local content will be one strategy in the ASEAN Economic Community (AEC). The power of information, knowledge, and culture from outside would be an additional strength of the nation without prejudice, obscure even to eliminate love learners will be cultural values of the nation and region.

In addition to the quality of the learning process, the lecturer is one of the essential components of an educational system in universities. Lecturer plays a role in facing AEC, especially in improving the quality of human resources. The lecturer is a determinant in creating a student who incidentally will be the candidates for employment. Lecturer determines the good and the poor quality of students as candidates for employment. When the lecturers have a good quality, they will generate prospective employment students. In the end, the lecturers also contributed to the advancement of participation in AEC. 
Associated with efforts to improve the quality of higher education, the competence of lecturers have a strategic role. Implementation or otherwise of the expected quality of higher education is determined by the quality of the lecturers in every field of their expertise (Hanafiah, 2004). A college which is innovative, qualified and responsive to global developments and local arrangements lies in the effort of its' development and improvement of the primary stakeholder which is their lecturers.

The role, duties and responsibilities of the lecturers play a role in achieving national education goals, namely the intellectual life of the nation, improve the quality of Indonesian, including the quality of faith and piety, character, and the mastery of science, technology, and art, to realize Indonesian society developed, just, prosperous, and civilized (Effendi, 2016). Given the magnitude of the role and responsibilities of the lecturers, it takes the effort to deliver lecturers who are professional and have competence in the field.

\section{The Condition of PTKIS}

\section{PTKIS history}

In its history, the existence of PTKIS was the forerunner of PTKI growth. The beginning of PTKI establishment came from PTKIS. PTKIS has been there before Indonesia's independence. Wishes and aspirations of Indonesian Muslims to establish Islamic universities have appeared in the 1930s. At that time Dr. Satiman wants to establish Islamic High School in several areas, namely: Jakarta, Solo and Jakarta. Furthermore, ten years later, on December 9, 1940, in Padang stood Islamic High School (SIT). SIT was set up by the union of teachers of Islamic religion (PGAI), although in the end it was closed because of the Japanese occupation in 1942. In 1945, in Jakarta stood Islamic High School (STI) with the head of Muhammad Hatta. STI aims to produce schoolars intellect. In 1948 STI moved to Yogyakarta and renamed the Indonesian Islamic University (UII). In 1950, one of the faculty in the Faculty of Religion UII submitted to the government and turned into a College of State Islamic Religion under PP 341950 (BAAKK UIN Syarif Hidayatullah, 2015).

PTKI currently consists of University, Institute, and the College. PTKI is under the guidance of Religious Affairs. But college guidelines in the Department of Religion must follow the guidelines set by the Ministry of National Education, as stated in the Decree of the National Education Minister of the Republic of Indonesia No. 234/U/2000.

PTKI managed by the Directorate General of Islamic Education (Direktorat Jenderal Pendidikan Islam/Ditjen Pendis). Ditjen Pendis is implementing the element under the Ministry of Religious Affairs. The 
number of both public and private PTKI managed by Ditjen Pendis as many as 717. The number PTKI by type are presented in Table 1 below.

Table 1. Number of PTKI by its' type

\begin{tabular}{clc}
\hline No. & \multicolumn{1}{c}{ Type PTKI } & Number \\
\hline 1 & State Islamic University (UIN) & 11 \\
\hline 2 & Islamic Institute (IAIN) & 26 \\
\hline 3 & State Islamic Institute (STAIN) & 18 \\
\hline 4 & FAI / University (PTKIS) & 93 \\
\hline 5 & Private Islamic Religion Institution (PTKIS) & 44 \\
\hline 6 & College (PTKIS) & 525 \\
\hline & Total & 717 \\
\hline
\end{tabular}

Source: Diktis MORA, 2016.

Regarding the access, since its inception, PTKI is the only channel of social mobility that is most important to Muslim children from various social strata far better than rural, suburban and urban areas. PTKI can be said to be a catalyst for the growth of the Muslim middle class. They are alumni of PTKI are now scattered in various fields of work. Therefore UIN, IAIN, STAIN and PTKIS should also encourage the mobility of motion that Muslim children be better planned and sustainable by providing quality education for all people.

That is the moral responsibility that is always attached to the PTKI identity. PTKI primary mandate is the development of religious sciences of Islam that should not forget to improve the morality side. Islamic values which are integrated with scientific aspects will become an additional value for its graduates. If a noble intention is realized, Muslims and people of Indonesia should be proud to have PTKI.

Lukman Hakim Saefuddin as the Minister of Religious Affairs said that the existence of PTKI in the community is not only required to meet the standards of education, but also to be able to build the unity based on the ethics of Islam and governance healthy in order to survive and build the characters of professional, systematic and continuous according to the needs of society. One of the fundamental problems in the management of education in environmental PTKI is the magnitude of society's expectations towards quality graduates and highly competitive, but it was not in line with expectations.

2. The challenge for PTKIS

PTKIS as educational institutions face the real challenge. AEC phenomenon as one of the impacts of globalization and internationalization actually provide challenges for the pursuit of progress and put themselves in 
order to align with other universities that have been advanced. Great effort, earnest, consistent and sustained course absolutely necessary for it (Ghafur, 2009).

PTKIS should try to improve the quality as defined in the National Standards so as to meet the expectations of stakeholders, including parents, community, the world of work, and the government. However, PTKIS still regarded as second-class educational institutions. The level of popularity and preference in graduates of SMA/MA/SMK against PTKIS under PTU/ PTN/PTS. In fact, there are still people who are not familiar with PTKIS institutions. Also, PTKIS also has had to adjust to the challenges of cultural patterns of society that can provide economic benefits for the students personally and community benefits.

Associated with AEC impact on educational institutions, PTKIS also not spared from the impact. As if PTKIS can follow the changes, it is possible that PTKIS will survive, but if PTKIS slow to respond the changes and unable to chase it, then sooner or later PTKIS will be left behind and abandoned. In fact, the position, existence and role of PTKIS in the context of a plural society like Indonesia is very strategic, including:

a. Islam as a religion that is full of nobleness values and complete, it can become important references and the most reliable moral guidance in maintaining the unity in diversity of Indonesian society. These all things can happen if Muslims truly practice the values of Islam in the order of religion, nation, and society. PTKIS position, as academic institutions and religious organizations, is in the determining position. Islam could provide a valuable contribution to the people and the country through analysis, studies, and research regarding religion.

b. PTKIS are at the bases of the Muslim community with all its variants. At the same time, PTKIS currently on pluralistic sociological environment either tribe, language, and religion. PTKIS as assets of local government can be a buffer area that serves as the guardian of morality, stability and social harmony based on religious values.

Therefore, in order PTKIS can face the free market era, it is necessary effort to improve the quality. PTKIS realize that quality is not an easy job. For making it real, it needs a long time, istiqãmah, responsibility, patience, commitment and noble intentions. However, that attitude has not completed if there were not professional attitudes such as self-confidence, discipline, hard work, have a clear vision, strong ability to compete fairly (fastabiqu \%khairãt), creative and innovative. Such attitudes must be owned by PTKIS. If the leadership of PTKIS has the capacity, capability and high integrity of the sort, then the ideals to create a quality of PTKIS will be realized. 
Muslim society as users of PTKI and government as one of the stakeholders are eager to the birth of PTKI that are famous, influential, and able to compete at international, regional and national (HS, 2013). Actually, PTKIS can do so, as long as there is sincerity. Opportunity to move forward and seize opportunities into major universities are not the monopoly of state universities. Private colleges also have the same chances and opportunities to advance and compete with other universities. In this era of competition, as now applies the adage that he who is qualified to lead.

3. Problems encountered by PTKIS

There are some problems encountered by PKIS (Kurniawan, 2014) include:

a. The amount decreases of public interest to send their children in PTKIS.

The decrease is due to the low level of public confidence in the universities in Indonesia. The high cost of education if it is associated with a per capita income of the people and does not guarantee acceptance in the world of work into the public driving factors for not sending their children to the college (Kurniawan, 2014). The decreased amount of general interest in college happens in Islamic based college, both public (PTKIN) and private (PTKIS)(“Suarasurabaya.net," 2008).

b. The low quality of PTKIS graduates due to the low input.

Most students who enter (as input) PTKIS are those who failed to enter in PTN and PTKIN. Thus, students who enter PTKIS are students whose quality is less, both regarding intelligence and economy. The low quality of graduates effect on the input (output). The low quality of PTKIS graduates causes the labor market can not absorb PTKIS graduates with a less ready-made excuse. Graduates with a long wait time work, indicate that the graduates were still not useful for society. The quality and relevance of graduate PTKI especially PTKIS is still a major factor in the nation's lack of competitiveness in the arena of free trade. The decline of the nation's economy, due to the low quality of human resources (HR), which manages economic resources. Even other factors sizeable role that are associated stereotypes and prejudice from the Institution of businesses or corporations that consider that graduates PTKIS less able to compete due to lack of skills and low quality and thus a new paradigm needs to be implemented by PTKIS to be able to print human resources ready in global competition.

4. The difficulty of financing.

The low number of students admitted to PTKIS, resulting in difficulty of funding. Because in general, operating costs PTKIS relies on education donations (SPP). Rarely, PTKIS who have other sources to fund academic 
programs. Meanwhile, assistance from the government yet open. However, there are also PTKIS who regularly obtain financing from local governments, especially those institutions that historically covered by local governments. Therefore, in order to meet the needs of PTKIS academic budgets, the government is expected to equalize the budget for public and private universities.

5. The poor quality of the academic process

The issue of to low budget in PTKIS impact the academic process. Funds are limited, leading to a tightening of the budget for teaching and learning. A reduction in the number of credit hours (SKS/Sistem Kredit Semester) to the minimum and the number of face-to-face weekly. In fact, it is possible to simplify the process of lectures and exams.

6. The poor quality of faculty research

Besides related to the budget, the other major issues that must be solved by is the poor quality of the research conducted by lecturers in PTKIS. During this time, the results only became ornate library shelf and never utilized by people to help to solve problems that occur in the community.

7. Qualification of teachers

As the mandate of Act No. 14 of 2005 on Teachers and Lecturers, that college teachers or lecturer should have a minimum qualification of a master's program for diploma or degree program; and graduates of doctoral programs, of course, has its challenges for school management of PTKIS because if it refers to the distribution of lecturers in 662 PTKIS are still many that do not conform to the standards that have been made. Of course, it also gives the image that PTKIS not been able to provide bids for the service user or the higher education community to develop their life skills in PTKIS.

\section{Growth and Quality Assurance in PTKIS}

Associated with college growth, today, the number of PTKIS increased. Carrying more than 600 PTKIS scattered throughout Indonesia, in the form of Colleges, Institute, and the University. Regarding quantity, the growth of PTKIS can be proud of. However, regarding quality, it is questionable how are the PTKIS real conditions? That is, the extent to which the quality of PTKIS compared with PTKIN and PTUN. Do PTKIS have been really into college, or just be a graduate of a certified institution and unnoticed out-come of its'?

Based on data submitted by the Religion Minister of the Republic of Indonesia, Lukman Hakim Saifuddin, in 2016 there were 209.195 students signed up PTKIN and received only 104.910 people. Of course, the rest of 
which is not accepted in PTKIN, become the blessing for PTKIS that often lack students. Especially for students who want to pursue religious sciences (Islamic Studies). In fact, it is also the number of programs offered by the Ministry of Religious Affairs to educators both PTKIN and PTKIS, such as scholarships doctoral program with full scholarship funding as many as 527 people and 330 participants $(62.2 \%)$ were from PTKIS recipients. MORA's offer has been an opportunity for PTKIS professors to follow the program of Academic Recharging, Post Doctor, the International Seminar and Sandwich. MORA's program became the government's efforts to boost the quality of teachers in PTKI, which should be used optimally. ("Menag," n.d.)

In addition to substantial funds and facilities available, many other factors to the success of higher education, including management/standardized management, networking and strategic cooperation, the involvement of the community and the business world in higher education. In that context, PTKIS should be able to keep pace. Private status should be used as an institutional capital. PTKIS should be able to create and innovate, utilizing the resources as much as possible, without any interference of other parties. Instead of relying on another helping. This institutional capital is a necessary quality assurance that should be developed to become the internal management of the institution (internal quality assurance). If the institution is internally strong, then the durability of the institutions will be strong, too. Gradually the internal forces that will encourage institutions and academia to improve themselves, be creative, and to make efforts to improve the quality.

The involvement of external parties such as Kopertais should be placed in the framework of institutional strengthening. As stipulated in the Decree of the Religion Minister of the number 155 in 2004, Kopertais task is to help the Ministry of Religious Affairs (now Ministry of Religion) in terms of monitoring, controlling, guidance and empowerment of private Islamic colleges (PTKIS). This function is carried out to ascertain whether the provision of education in PTKIS runs according to the applicable rules or not. Kopertais act as an external quality assurance, which served as a supervisor, controllers, and supervisors PTKIS in developing institutional capacity (capacity building), to improve the quality, accountability, implementing campus autonomy properly, providing services to the students, empower owned resources, etc. Kopertais is not a policeman in charge of overseeing PTKIS so punishing PTKIS wrong and controlling the activities of academic and student affairs. However, Kopertais is necessary to ensure, guarantee, and whether educate the correct or not in PTKIS.

Quality assurance in PTKIS (according to indicators of quality assurance agencies), does not only give hope to the presence of the superior 
to manage different areas of life, but also to enhance the quality of civilization, the quality of cultural life, and human dignity.

Public accountability and quality assurance college apart is determined by the condition of internal governance and organization of the university, is also shaped by interactions with people outside the college. As a public institution, PTKIS should be open and free to be controlled. PTKIS should not sterile to the demands, dynamics, and control society. Therefore, accountability and quality assurance of PTKIS succession are determined by the extent to which a given community monitoring and quality assurance agency (Ghafur, 2009).

Both within the education system centralized or decentralized, quality assurance remains a major issue, which includes three aspects, namely competence, accreditation, and accountability. Graduates are deemed to have met all the requirements, and competencies demanded entitled to a diploma or certificate that is accredited by the National Accreditation Board which in this case is handled by BAN PT. To get it, of course, educational institutions need to guarantee the quality in order to be credible and accountable as well as professionals in the process of implementation. In other words, in the context of education, accountability is the ability of an institution to maintain the quality of its output so that it can be accepted by the community. In line with the increasing public demand for education quality, the accountability issue of educational institutions is very crucial in Indonesia now. The genesis of Law No. 12 of 2012 on Higher Education became one of serious consequence to the government in the management of universities. If in the past, people tended to accept all that is given by educators, at present, they have the critical thinking, not necessarily take all submitted educators. Society as a consumer who has to pay the cost of education is high enough to feel entitled to a payoff that is a better education for themselves and their families.

Efforts to achieve accountability of institutions is not an easy task. Therefore, it takes a scheme and curriculum design formulas that match the needs of the labor market that continue to grow and thrive as technological developments and information. To be able to develop PTKIS based on a model of educational institutions accountable management needs to consider a number of aspects such as; commitments outlined in the curriculum, adequate infrastructure, consistency in the delivery of education, a clear set of rules, and a financial management system that can be assessed and measured regarding levels of openness by the institute of public accountants. If it is not executed then an PTKIS institution to be able to run an accountable system of educational institutions becomes impossible. When referring to the five problems that have been described, almost in every PTKIS the problem 
faced due to the paradigm of education in Indonesia today has not been able to run it well, the biggest obstacle because many educational institutions are weak in almost all aspects of the above therefore the needs to be a more serious and transparent in spurring PTKIS that is credible and accountable are important.

The reason for the importance of educational institutions should carry out accountability in the process of organizing education refers to Law No. 12 of 2012 on Higher Education, what is intended to the principle of accountability is the ability and commitment to take responsibility for all activities undertaken by Higher Education to all stakeholders in accordance with the provisions of the legislation. Accountability, among others, can be measured from the ratio between students and lecturers, adequacy of facilities and infrastructure, implementation of education quality, and competencies of graduates.

The quality of academic services and management should be a grave concern in the higher education management in the era of globalization. The study results of Danim (2002) that structural labor, academic, and management in higher education environments tend to have the same opinion, namely academic and management service that are qualified and complement each other which are the prerequisite for an effective process of higher education. Each are assumed to be able to carry out their duties and functions (both strategic and operational levels) by using the fundamental principle of uniformity in the work. The academic and management services are still dominantly guided by the rules of guidance from stakeholders. While the potential and human resources that exist in each of the institutional units are required to make adjustments at the level of creativity.

Some of the weakness that occurs in Indonesian universities, among others: (1) unhealthy organization; characterized by low quality, education (academic) is often irrelevant, (2) PTN is part of the government bureaucracy; so it's not/less powerful, slow, too often intervened, (3) is only liable to the direct superior, not to stakeholders, and (4) the initiative always comes from outside (in the form of instruction) (Brojonegoro, 2005). Changing government role from the provider into a regulator, a provider of funds (in the context to intervene in the market mechanism, ensure the accessibility, control disparity, and the facilitator is required. Thus, the empowerment of college is expected.

PTKIS ideally can be responsible for the whole process of its institution's implementation as stipulated in article 78 of Law number 12 of Universities that governing accountability to run by universities both academic and non-academic., to the entire stakeholders. For example, in the budget areas the audit was taken internally and externally conducted by 
public accountants, then, enables stakeholders to access it as a form of transparency. Another example is in the academic field, it is an appropriate time for PTKIS to open access to the results of research conducted by students and teachers for some people, this is, also, not only to publish the results of research but also to prevent the level of plagiarism.

Furthermore, it is because college is an educational organization that has an interest in the preservation of culture, values, the independence, and also businesses. Therefore, universities are required to keep abreast of the times (fashionable). Education is regarding the dimensions of the system, paradigms, and culture. The culture of colleges also needs to be adjusted to the paradigm shift in the world, which is oriented to the customer, customer satisfaction, disclosure management, and quality assurance. Education quality assurance is a meeting point between the expectations of the users (client) and education service providers (providers) (Effendy, 2007).

With the cooperation between universities in Southeast Asia in Asean University Networks Standard for Higher Education (AUN-SHE) program which is part of a higher education cooperation, which for Indonesia initiated by Universitas Indonesia, Gadjah Mada University, and Institut Teknologi Bandung. That opens opportunities for cooperation in the field of teacher training, teaching, and English language training, Vocational and Technical Education and the use of ICT in education which is already developed in the ASEAN region ("Kerjasama Fungsional Asean," n.d.). Of course, it also needs to be pursued and executed by PTKIS as part of the process to increase its participation in the development of accountable higher education institutions.

From a number of demands to improve the quality of education, then the steps that need to be done by PTKIS certainly transform holistically and integrally, by running a center of excellence based academic, develop a research model that adapts to the needs of industry, creating graduates according to the market work, and began to implement a virtual system based on the website. The fourth part of this would be the most important requirement for PTKIS because, as in RPJMN Indonesia in 2015-2019, that intertwined with the cooperation in various sectors in the region, is a real form of a strategy to strengthen the first concentric circle of foreign policy, through ideas, concepts and initiatives that are able to put back in Indonesia as a country that is far more important role in Southeast Asia and East Asia (Direktorat Politik dan Komunikasi Bappenas, 2015).

If the program that has been launched by the government in associated with AUN-SHE is not utilized and also run by PTKIS then, of course, as an institution of higher education that produces graduates who are certified, will not be accepted globally. Even with such conditions the issued 
will be cornering that PTKIS graduates are not able to compete in the global competition. Therefore, encouraging in pushing PTKIS to start chasing the lateness and raise the standard needs to be done to improve the management accountable and require more professional educators. Although in the case of PTKIS still run management principles that are flexible and dynamic. The hope with a number of programs, which have been created and assembled by the government with AUN-SHE allows PTKIS to develop in accordance with the potential and meet external demands that is faced, including the era of the ASEAN Economic Community.

\section{CONCLUSION}

The agreement of ASEAN Economic Community is already implemented. Therefore, Indonesia has to prepare well. It also affects Private Islamic Religion Institution (PTKIS). The stakeholders of PTKIS are required to respond immediately to this condition. PTKIS have big chance in producing skilled and qualified graduates, on the other hand their status should be used as an institutional capital to empower their human resources. It is expected through the implementation of the college accountability management, public trust would increase. These efforts include: strengthening the competence and quality of lecturers, implementing the curriculum that is responsive to change, upgrading infrastructure and facilities that are expected to answer the challenges of the ASEAN Economic Community era.

\section{BIBLIOGRAPHY}

ASEAN (Ed.). (2009). Roadmap for an asean community, 2009-2015. Jakarta: Association of Southeast Asian Nations Secretariat.

Asmawi, M. R. (2005). Strategi meningkatkan lulusan bermutu di perguruan tinggi. Makara Sosial Humaniora, 66-71.

BAAKK UIN Syarif Hidayatullah. (2015). Pedoman akademik program strata 1 universitas islam negeri syarif hidayatullah jakarta 2015/2016. Retrieved from http://www.uinjkt.ac.id/id/.

Brojonegoro, S. S. (2005). Landasan implementasi perguruan tinggi sebagai badan hukum milik negara. Universitas Sriwijaya. Retrieved from http://www.unsri.ac.id/.

Danim, S. (2002). Inovasi pendidikan: dalam upaya peningkatan profesionalisme tenaga kependidikan. Bandung: Pustaka Setia.

Darmaningtyas. (2007). Realitas pemberlakukan uan/un. EDUKASI Jurnal Penelitian Pendidikan Agama Dan Keagamaan, 5(1).

Direktorat Politik dan Komunikasi Bappenas. (2015). Reviu kelembagaan: kesiapan indonesia dalam menghadapi masyarakat asean 2015. Retrieved from http://ditpolkom.bappenas.go.id/. 
Effendi, M. (2016). Buku pedoman sertifikasi pendidik untuk dosen tahun 2010. Jakarta. Retrieved from https://muhariefeffendi.files.wordpress.com.

Effendy, M. (2007). Implementasi manajemen pendidikan tinggi pengalaman universitas muhammadiyah malang. Retrieved from http://elibrary.pascasarjana-stiegr.ac.id/index.php?p=show_detail\&id $=635$.

Ghafur, A. H. S. (2009). Manajemen mutu, penjaminan mutu dan internasionalisasi perguruan tinggi di indonesia. Jakarta: UI Press.

Hakim, M. F. (2015). Asean community 2015 dan tantangannya terhadap pendidikan islam di indonesia. Jumal Review Politik, 4(2), 165-191.

Hanafiah, J. (2004). Pengelolaan mutu pendidikan tinggi. Jakarta: BKSPTN Barat Depdikbud RI dan REDS USAID-DIKTI-JICA.

HS, M. (2013). Diktis | artikel: paradigma pendidikan tinggi dan posisi perguruan tinggi agama islam. Retrieved from http://diktis.kemenag.go.id/NEW/index.php?berita=detil\&jenis=artikel \&jd=182\#.WEjgjbn5631.

Kerjasama Fungsional Asean. (n.d.). Retrieved from http://www.kemlu.go.id/id/Default.aspx.

Kurniawan, A. (2014). Faktor diterminan mutu madrasah aliyah. Retrieved from http://repository.upi.edu/11378/4/D_ADP_0800782_Chapter1.pdf.

Lexy J, M. (2007). Metodologi penelitian kualitatif (Revised Edition). Bandung: Rosda Karya.

Menag: ptki tunjukkan perkembangan yang lebih baik. (n.d.). Retrieved from https://www.kemenag.go.id/berita/409340/menag-ptki-tunjukkanperkembangan-yang-lebih-baik?lang=id.

Nandika, D. (n.d.). Pendidikan di tengah gelombang perubahan. Jakarta: LP3ES.

Nassar, J. R. (2009). Globalization and terrorism: the migration of dreams and nightmares. Rowman \& Littlefield Publishers.

Redaksi Syncore Magz. (2015, January 8). daily Rudy. Retrieved from https://dailyrudy.wordpress.com/.

Schwab, K., Sala-i-Martin, X., Dervis, K., \& World Economic Forum. (2010). The global competitiveness report 2010-2011. Geneva: World Economic Forum.

Suarasurabaya.net. (2008, August 22). Retrieved from http://www.suarasurabaya.net/.

UNDP (Ed.). (2011). Sustainability and equity: a better future for all. Houndmills: Palgrave Macmillan.

Zamroni, M. I. (2012). Pengembangan Madrasah Berparadigma Pembangunan Berkelanjutan. Jurnal Kawistara, 2(1). 